\title{
Fifty years of wheat breeding in Southern Brazil: yield improvement and associated changes
}

\author{
Osmar Rodrigues ${ }^{(1)}$, Julio César Barreneche Lhamby ${ }^{(1)}$, Agostinho Dirceu Didonet( ${ }^{(2)}$ \\ and José Abramo Marchese ${ }^{(3)}$
}

\begin{abstract}
(1)Embrapa Trigo, Caixa Postal 451, CEP 99001-970 Passo Fundo, RS, Brazil. E-mail: osmar@cnpt.embrapa.br, julio@cnpt.embrapa.br (2)Embrapa Arroz e Feijão, Caixa Postal 179, CEP 75375-000 Santo Antônio de Goiás, GO, Brazil. E-mail: didonet@cnpaf.embrapa.br (3)Universidade Tecnológica Federal do Paraná, Pato Branco, PR, Brazil. E-mail: abramo@utfpr.edu.br
\end{abstract}

\begin{abstract}
The objective of this study was to assess the impact of genetic breeding on grain yield, and to identify the physiological traits associated to the increment in yield and their related growth processes, for wheat cultivars grown in Southern Brazil, in the past five decades. Seven wheat cultivars released between 1940 and 1992, were compared for physiological aspects associated with grain yield. Grain yield, biological yield, biomass partitioning, harvest index and grain yield components were also determined. The number of grains per square meter was more affected by plant breeding and was better correlated with grain yield $(r=0.94, p<0.01)$ than with grain weight $\left(r=-0.39^{\text {ns }}\right)$. The higher number of grains per square meter was better correlated with the number of grains per spike in the modern cultivars than in the older ones. The genetic gain in grain yield was $44.9 \mathrm{~kg} \mathrm{ha}^{-1}$ per year, reflecting important efforts of the breeding programs carried out in Southern Brazil. Grain yield changes, during the period of study, were better associated with biomass production $(r=0.78, p<0.01)$ than with harvest index $(r=0.65, p<0.01)$.
\end{abstract}

Index terms: Triticum aestivum, genetic gain, harvest index, yield components.

\section{Cinqüenta anos de melhoramento de trigo no Sul do Brasil: melhoramento na produção e mudanças associadas}

\begin{abstract}
Resumo - O objetivo deste trabalho foi avaliar a contribuição do melhoramento genético na produtividade de grãos e identificar as características fisiológicas, associadas ao incremento do rendimento, e os processos de crescimento que as produzem. Foram estudadas sete cultivares de trigo, extensivamente cultivadas na região Sul do Brasil entre 1940 e 1992. As cultivares foram comparadas quanto ao rendimento de grãos, produção biológica, índice de colheita, partição de biomassa e componentes do rendimento. O número de grãos por metro quadrado foi o componente mais afetado pelo melhoramento genético, no período de 52 anos abrangidos pelo estudo, e esteve mais correlacionado ao rendimento de grãos $(r=0,94, p<0,01)$ do que o peso de grãos $\left(\mathrm{r}=-0,39^{\mathrm{ns}}\right)$. O maior número de grãos por metro quadrado, observado nas cultivares modernas, foi mais correlacionado com seu número de grãos por espiga, em relação às cultivares antigas, o que caracteriza a importância do período de pré-antese na produção de grãos. O ganho genético na produção de grãos foi de $44,9 \mathrm{~kg} \mathrm{ha}^{-1}$ por ano e reflete o importante esforço dos programas de melhoramento genético desenvolvidos no Sul do Brasil. As variações em rendimento de grãos, ocorridas no período de estudo, estiveram mais associadas à produção de biomassa $(r=0,78, p<0,01)$ do que ao índice de colheita $(r=0,65, p<0,01)$.
\end{abstract}

Termos para indexação: Triticum aestivum, ganho genético, índice de colheita, componentes de rendimento.

\section{Introduction}

Investigations regarding genetic gains, involving direct comparisons between number of cultivars released at different dates, must be carried out free of confusion arose from technological progresses which took place over the period under study. According to Slafer \& Satorre (1994), the advance in yield potential may result from genetic gain in grain yield potential; and also in resistance to diseases, reduced lodging, tolerance to environmental constraints (from other genetic improvement); and in development of machinery and equipment, better agrochemical usage, more appropriate decisions as to seeding date and rate (non-genetic or agronomic). In order to isolate these components and avoid confusions, studies should consider management practices, soil 
conditions, lodging control, disease control and other technological advances, all of which may have experienced changes throughout the period of the study (Slafer \& Andrade, 1991).

Such studies allowed the understanding of the main morphological and physiological traits associated with yield potential, and the development of new plant selection criteria, associated with yield increments (Slafer \& Andrade, 1989; Tollenaar, 1991). The technique used for such purpose consisted of comparative studies of cultivars released at different times to understand the causes of variation in grain yield and the associated growth processes. In this way, studies with wheat were developed in the United Kingdom (Austin et al., 1989), USA (Deckerd et al., 1985), Mexico (Waddington et al., 1986, 1987), Australia (Perry \& D'Antuono, 1989), Argentina (Slafer \& Andrade, 1989), and even with other crops like corn (Tollenaar, 1991), soybean (Gay et al., 1980), and barley (Wych \& Rasmusson, 1983).

There is an indication that the cultivars grown in Southern Brazil, before the seventies, yielded around 14\% less than the cultivar Nobre (released in 1969 and used as tester), while the cultivars released after that decade exceeded Nobre by $22 \%$ (Moreira et al., 1982). There is available data showing genetic gains of $17.3 \mathrm{~kg} \mathrm{ha}^{-1}$ per year over the period from 1940 to 1992 (Nedel, 1994).

Investigations carried out in several countries indicated that the increase in the harvest index is the main factor associated to the advance in the genetic potential of grain yield in wheat (Austin et al., 1980; Perry \& D'Antuono, 1989; Slafer \& Andrade, 1989). In Brazil, the scarce available information shows that the higher grain yields observed in the new cultivars, compared to the old ones, was basically due to the increase of harvest index (Nedel, 1994). However, such results must be interpreted carefully, because one out of two years of the studies was characterized by heavy water stress. Similar results have been observed in barley (Riggs et al., 1981), oats (Lawes, 1977), and durum wheat (Waddington et al., 1987). Nevertheless, studies developed in Mexico showed that grain yield did not correlate with harvest index but with an increase in the biological production (Waddington et al., 1986). A positive correlation between biomass at maturity and years in which cultivars were released was also observed in Canada, and the genetic gain in biomass explained most of the genetic gain in yield (Hucl \& Baker, 1987).
Statistics obtained in Brazil, from farm wheat grain yields between 1962 and 1992, in Rio Grande do Sul, indicate that grain yield increased at a rate of $16.2 \mathrm{~kg} \mathrm{ha}^{-1}$ per year. Such increase in grain yield began in the seventies, with the release of cultivars with shorter height, earlier cycle, and higher yield potential, in addition to resistance or tolerance to the main diseases. Improved soil management, weed and disease control, seeding time and rate, fertilization and crop rotation, associated with the introduction of higher yielding cultivars, made grain yield potential higher than $4,000 \mathrm{~kg} \mathrm{ha}^{-1}$. Howerer, it is yet to be determined to which extent grain yield increase, recorded over the last 50 years in Brasil, was due to the improvement of genetic potential of grain yield, instead of resistance/tolerance to diseases, lodging or better cultural practices. Crop physiological characteristics associated to such yield increment, as well as to growth processes producing them, remain unknown.

Therefore, the objectives of this study were to assess the impact of genetic breeding on grain yield, independently of the tolerance/resistance to diseases and lodging, and to identify the physiological traits associated to the increment in yield and to associated growth processes, for wheat cultivars grown in Southern Brasil, in the past five decades.

\section{Material and Methods}

Field trials were carried out in 1993, 1994, and 1995, at the Centro Nacional de Pesquisa de Trigo (National Wheat Research Center), in Passo Fundo $\left(28^{\circ} 15^{\prime} \mathrm{S}\right.$, $\left.52^{\circ} 24^{\prime} \mathrm{W}, 687 \mathrm{~m}\right), \mathrm{RS}$, Brazil. Seven wheat cultivars, released between 1940 and 1992 (Table 1), were used to estimate the breeding progress in Southern Brazil. The number of days from emergence to terminal spikelet and to anthesis were determined (Table 2). The selection of the cultivars, one for each decade, was based on the outstanding participation in the wheat cropped area in Southern Brazil. Cultivar IAS 54 was included in the seventies, because it represented a new plant type.

Table 1. Name, year of release and genealogy of wheat cultivars.

\begin{tabular}{lcl}
\hline Cultivar & $\begin{array}{c}\text { Year of } \\
\text { release }\end{array}$ & \multicolumn{1}{c}{ Genealogy } \\
\hline Frontana & 1940 & Fronteira / Mentana \\
BH 1146 & 1955 & PG 1//Fronteira /Mentana \\
Nobre & 1969 & Colotana 82451/Yaktana 54//Colotana 296-52 \\
IAS 54 & 1970 & IAS 16/4/Norin 10B17/Yaqui 53//Yaqui 50/3/KT 54B \\
CNT 8 & 1976 & IAS 20/ND 81 \\
Trigo BR 23 & 1987 & C. Caminos/Alondra Sib/3/IAS 54-20/Cotiporã//CNT8 \\
Embrapa 16 & 1992 & Hulha Negra / CNT 7 //Amigo/CNT 7 \\
\hline
\end{tabular}


The soil was a typical, red, dystrophic Latosol, with the following chemical composition: in $1993\left(\mathrm{pH}_{\mathrm{H}_{2} \mathrm{O}}=5.3\right.$, $\mathrm{pH}_{\mathrm{SMP}}=5.9, \mathrm{Al}^{3+}=0.5$ mmol $_{\mathrm{c}} \mathrm{kg}^{-1}, \mathrm{Ca}^{2+}=60.2$ mmol $_{\mathrm{c}} \mathrm{kg}^{-1}$, $\mathrm{Mg}^{2+}=21.6$ mmol $_{\mathrm{c}} \mathrm{kg}^{-1}, \mathrm{P}=21.4 \mathrm{mg} \mathrm{dm}^{-3}, \mathrm{~K}=132 \mathrm{mg} \mathrm{dm}^{-3}$, and $\left.\mathrm{MO}=22 \mathrm{~g} \mathrm{~kg}^{-1}\right) ; \quad$ in $1994 \quad\left(\mathrm{pH}_{\mathrm{H}_{2} \mathrm{O}}=5.7\right.$, $\mathrm{pH}_{\mathrm{SMP}}=5.8, \mathrm{Al}^{3+}=0.5$ mmol $_{\mathrm{c}} \mathrm{kg}^{-1}, \mathrm{Ca}^{2+}=46.6 \mathrm{mmol}_{\mathrm{c}} \mathrm{kg}^{-1}$, $\mathrm{Mg}^{2+}=30.1 \mathrm{mmol}_{\mathrm{c}} \mathrm{kg}^{-1}, \mathrm{P}=15.5 \mathrm{mg} \mathrm{dm}^{-3}, \mathrm{~K}=120 \mathrm{mg} \mathrm{dm}^{-3}$, and $\left.\mathrm{MO}=26 \mathrm{~g} \mathrm{~kg}^{-1}\right)$; and in $1995\left(\mathrm{pH}_{\mathrm{H}_{2} \mathrm{O}}=5.5\right.$, $\mathrm{pH}_{\mathrm{SMP}}=5.8, \mathrm{Al}^{3+}=1.5$ mmol $_{\mathrm{c}} \mathrm{kg}^{-1}, \mathrm{Ca}^{2+}=58.2 \mathrm{mmol}_{\mathrm{C}} \mathrm{kg}^{-1}$, $\mathrm{Mg}^{2+}=24.1 \mathrm{mmol}_{\mathrm{c}} \mathrm{kg}^{-1}, \mathrm{P}=22.9 \mathrm{mg} \mathrm{dm}^{-3}, \mathrm{~K}=100 \mathrm{mg} \mathrm{dm}^{-3}$, and $\left.\mathrm{MO}=24 \mathrm{~g} \mathrm{~kg}^{-1}\right)$. In each year, the experiment was set up in a complete randomized block design, with four replications. The plots consisted of 12 rows, with $0.20 \mathrm{~m}$ apart and $6 \mathrm{~m}$ long.

Fungicide treated seeds were mechanically sown on 21 June 1993, 12 July 1994 and 23 May 1995, in a sowing density of 330 viable seeds per square meter. One week after seedling emergence plots were thinned to 300 plants per square meter.

The amount of fertilizer used was 300, 250, and $250 \mathrm{~kg} \mathrm{ha}^{-1}$ (NPK 5-20-25), incorporated before sowing in 1993, 1994 and 1995, respectively. After seedling emergence, $50 \mathrm{~kg} \mathrm{ha}^{-1} \mathrm{~N}$ were applied at the double ridge stage (Nerson et al., 1980), and $50 \mathrm{~kg} \mathrm{ha}^{-1} \mathrm{~N}$ at terminal spikelet stage (Nerson et al., 1980), in 1993, as topdressing; $45 \mathrm{~kg} \mathrm{ha}^{-1} \mathrm{~N}$ were applied in 1994 and 1995 , also at these stages. The double ridge and terminal spikelet stages were determined by desiccation of four main stems, in each plot, every 2 to 3 days. Fungicide was systematically applied from emergence to maturity to avoid disease damages. Weeds were periodically removed by hand. To prevent lodging, nets were installed at $0.2 \mathrm{~m}$, above soil surface, when plants were near terminal spikelet stage. Plots were irrigated to assure sufficient water availability to plants (Table 3). Weather from May to November, especially May and June, were critical for yield determination and varied significantly between years (Table 3 ).

Table 2. Days from emergence to terminal spikelet appearance (TSA) and anthesis (Ant), for seven cultivars in 1993, 1994, and 1995, in Passo Fundo, RS, Brazil.

\begin{tabular}{|c|c|c|c|c|c|c|}
\hline \multirow[t]{2}{*}{ Cultivar } & \multicolumn{2}{|c|}{1993} & \multicolumn{2}{|c|}{1994} & \multicolumn{2}{|c|}{1995} \\
\hline & TSA & $\overline{\mathrm{Ant}}$ & TSA & $\overline{\text { Ant }}$ & TSA & Ant \\
\hline Frontana & 56 & 88 & 41 & 72 & 50 & 85 \\
\hline BH 1146 & 49 & 85 & 40 & 70 & 46 & 76 \\
\hline Nobre & 56 & 88 & 40 & 72 & 50 & 82 \\
\hline IAS 54 & 56 & 88 & 44 & 76 & 50 & 85 \\
\hline CNT 8 & 64 & 95 & 47 & 80 & 55 & 94 \\
\hline Trigo $\mathrm{Br} 23$ & 54 & 91 & 40 & 76 & 43 & 82 \\
\hline Embrapa 16 & 56 & 95 & 44 & 81 & 43 & 84 \\
\hline
\end{tabular}

Plant samples were taken at anthesis and physiological maturity. Plants previously marked in an area of $0.2 \mathrm{~m}^{2}$ were cut at ground level, when the respective stages were reached. Plants were, then, separated in stems (including leaf sheaths), blades of green/dry leaves, and spikes. Dry weight of the plant materials was determined. Harvest index (grain yield: above-ground biological yield ratio at physiological maturity) was calculated for each plot. Plant height measurements were made from the soil surface to the base of the spike on four main stems of each plot.

Data from three years of investigation were submitted to analysis of variance, and cultivar means were compared by the Tukey test $(\mathrm{p}<0.05)$. The degree of association between the different variables under study was estimated using linear or quadratic regression models. Also, stepwise multiple regressions were used to estimate the relative contribution of biomass and harvest index to increase yield potential, using SAS (SAS Institute, 1990).

\section{Results and Discussion}

Analyzing the duration of the period from emergence to anthesis, it can be seen that wheat development was affected by environmental conditions. The duration was bigger in 1993 and 1995, due to a longer period from emergence to terminal spikelet appearance (TSA), even though they had shorter period TSA to anthesis (Table 2).

During the first two years of the study, a positive correlation between grain yield and the subperiod from emergence to anthesis was found. However, no correlation was found in 1995, despite the highest average grain production among the years.

Table 3. Mean temperature, rainfall and irrigation, from May to December, in 1993, 1994, and 1995, Passo Fundo, RS, Brazil.

\begin{tabular}{cccccccccc}
\hline Year & May & Jun. & Jul. & Aug. & Sep. & Oct. & Nov. & Dec. \\
\hline \multicolumn{7}{c}{ Mean temperature $\left({ }^{\circ} \mathrm{C}\right)$} \\
1993 & 14,8 & 12,6 & 11,7 & 14,0 & 14,4 & 19,3 & 19,9 & 21,8 \\
1994 & 16,8 & 12,4 & 13,5 & 14,5 & 16,6 & 18,8 & 19,2 & 23,5 \\
1995 & 14,1 & 13,7 & 15,2 & 15,4 & 15,4 & 16,7 & 21,3 & 23,0 \\
\hline & & & \multicolumn{7}{c}{ Rainfall $(\mathrm{mm})$} \\
1993 & 176 & 137 & 284 & 15 & 136 & 154 & 274 & 259 \\
1994 & 152 & 198 & 243 & 46 & 161 & 308 & 138 & 235 \\
1995 & 21 & 174 & 136 & 76 & 135 & 198 & 78 & 31 \\
\hline & & & \multicolumn{7}{c}{ Irrigation (mm) } \\
1993 & - & - & - & 46 & - & - & - & - \\
1994 & - & - & - & - & 23 & - & - & - \\
1995 & - & 42 & - & - & - & - & - & - \\
\hline
\end{tabular}


If it is considered just the period from terminal spikelet to anthesis (TS-anthesis), a period that corresponds mostly to spike growth and, consequently, very important for the determination of the number of grains per square meter (Fisher, 1985), a positive correlation is found with grain yield in every year of the study focus (Figure 1). However, it is possible that the lack of correlation between grain yield and the duration of the period emergence-anthesis, in 1995, is due to the effect of air temperatures on the duration of the vegetative developmental stages (Table 3) due to different sowing dates among years. It has to be considered that the sowing date in 1995 was in May, with higher average daily temperatures compared to June and July (Table 3), causing a reduction on the length of the vegetative stage of development and the establishment of the subperiod ATS-anthesis in lower temperatures that allowed an elongation of this subperiod.

Grain yield of modern cultivars significantly exceeded those of old cultivars (Table 4). Changes in yield, associated to the years of release of cultivars, were described by a quadratic model: $y=0.001 x^{2}-0.1056 x+$ $5.0397(\mathrm{p}<0.01)$. Such mathematical relationship suggests the occurrence of two quite distinct periods in breeding potential of yield: one before and other after the seventies. Such differential behavior may be a result of the distinct strategies adopted in plant selection throughout these periods. Grain yield of the cultivars released up to the seventies were similar. However, the cultivars released after these period showed higher grain

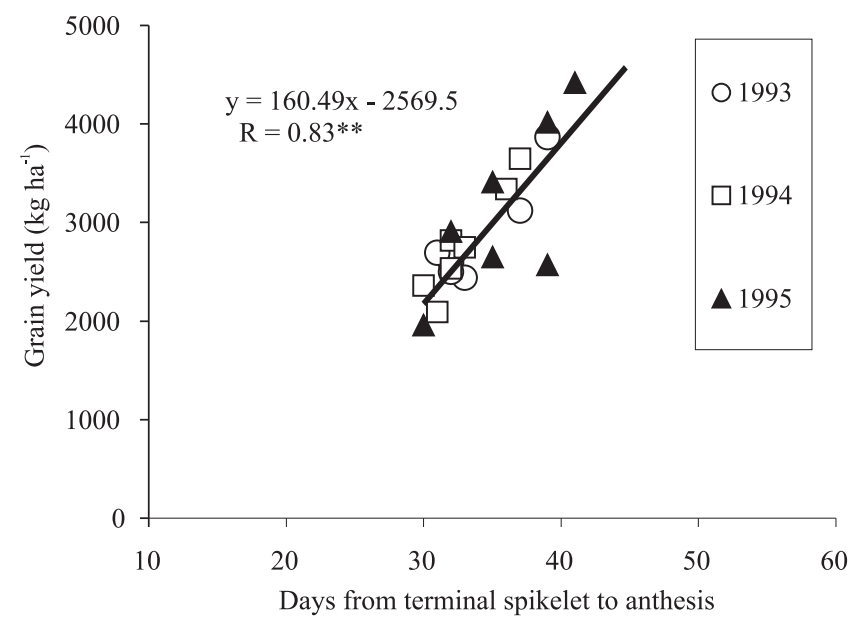

Figure 1. Association between the time from terminal spikelet to anthesis and grain yield of wheat cultivars in 1993, 1994, and 1995 experiments. yield. The results from this work are similar to those observed in England (Austin et al., 1980, 1989), New Zealand (McEvan \& Cross, 1979), Argentina (Slafer \& Andrade, 1989; Slafer \& Satorre, 1994), Canada (Hucl \& Baker, 1987), and Australia (Perry \& D'Antuono, 1989). Such behavior of cultivars, released in this first phase, possibly reflects the aim of plant breeding in selecting for resistance/tolerance to diseases, toxic aluminum, instead of increasing yield potential.

Selection for increasing protein content was pointed out as responsible for the low rates of advance grain yield potential (Slafer \& Andrade, 1989). However, selection for grain protein increase did not receive attention from plant breeders in Southern Brazil in the first phase. In a second phase, after the seventies, it seems that plant breeding work aimed to increase yield potential, in association with other characteristics that could be of interest. These results also made evident that the advance in yield, after the seventies, had not reached its limit, suggesting that plant breeding programs could be able to significantly increase the yield potential.

Considering the period between 1955 and 1992, when the regression analysis of yield over years of release was statistically significant $(\mathrm{r}=0.87, \mathrm{p}<0.01)$, a genetic gain of $44.9 \mathrm{~kg} \mathrm{ha}^{-1}$ per year (Figure 2) was obtained. Such gain was higher than the one obtained by Nedel (1994) in similar trials. Slafer \& Andrade (1991) summarized studies of genetic progress in the yield of bread wheat in many countries, and reported annual rates of progress from $5.8 \mathrm{~kg} \mathrm{ha}^{-1}$ (India) to $58.4 \mathrm{~kg} \mathrm{ha}^{-1}$ (Mexico). Countries like Argentina, Canada, Australia, England, and USA produced intermediate values of genetic gain, suggesting a similar efficiency among their genetic breeding programs (Slafer \& Andrade, 1991). According to these authors, the genetic gains observed

Table 4. Mean grain yield and height for the cultivars, in 1993,1994, and 1995 experiments $^{(1)}$.

\begin{tabular}{lllll}
\hline Cultivar $^{(2)}$ & \multicolumn{3}{c}{${\text { Grain yield }\left(\mathrm{kg} \mathrm{ha}^{-1}\right)}$} & Height $^{(3)}$ \\
\cline { 2 - 4 } & 1993 & 1994 & 1995 & $(\mathrm{~cm})$ \\
\hline Frontana & $2,587 \mathrm{c}$ & $2,090 \mathrm{f}$ & $2,647 \mathrm{de}$ & $93.25 \mathrm{a}$ \\
BH 1146 & $2,442 \mathrm{c}$ & $2,361 \mathrm{e}$ & $1,959 \mathrm{e}$ & $90.00 \mathrm{~b}$ \\
Nobre & $2,499 \mathrm{c}$ & $2,537 \mathrm{de}$ & $2,906 \mathrm{~cd}$ & $88.75 \mathrm{c}$ \\
IAS 54 & $2,598 \mathrm{c}$ & $2,818 \mathrm{c}$ & $3,411 \mathrm{bc}$ & $79.00 \mathrm{~g}$ \\
CNT 8 & $2,695 \mathrm{bc}$ & $2,748 \mathrm{~cd}$ & $2,569 \mathrm{de}$ & $88.25 \mathrm{~d}$ \\
Trigo BR 23 & $3,119 \mathrm{~b}$ & $3,342 \mathrm{~b}$ & $4,014 \mathrm{ab}$ & $82.25 \mathrm{f}$ \\
Embrapa 16 & $3,868 \mathrm{a}$ & $3,647 \mathrm{a}$ & $4,417 \mathrm{a}$ & $85.25 \mathrm{e}$ \\
\hline
\end{tabular}

(1) Means followed by the equal letters, within a column, were not significantly different $(\mathrm{p}<0.05)$ as tested by Tukey's multiple range test. ${ }^{(2)}$ Genotypes are ordered from oldest to newest. ${ }^{(3)}$ Height from ground level to the base of the spike. 
over the last years may be a result of similar strategies adopted in the respective genetic breeding program.

Compared to results obtained elsewere, the rate of progress in the yield of spring bread wheat in Southern Brazil is higher than those obtained in Argentina, Australia, Canada, England and the United State of America (Slafer \& Andrade, 1991), and lower than those obtained in Mexico in the same period of time. However, these estimates in genetic progress in countries like Australia, England and USA are representative of periods of about a century or more. The genetic gain in Southern Brazil was obtained in the last 40 years, when modern and productive cultivars were introduced. This could cause higher impact on the yield potential and would make comparison of the data more difficult. However, the comparison of these data with genetic gains obtained in Argentina and Canada, for the last 50 years, indicates that the breeding programs carried out in Southern Brazil may have been more effective in increasing yield potential.

The genetic gain ( $\mathrm{kg} \mathrm{ha}^{-1}$ per year) calculated in this way is highly affected by environmental conditions during the experiment (Austin et al., 1989; Perry \& D'Antuono, 1989). To address these problems, the use of relative estimate of genetic gain (the ratio between regression coefficient and average yield of the experiment) has been suggested for direct comparisons between experiments. The relative genetic gain in the present study

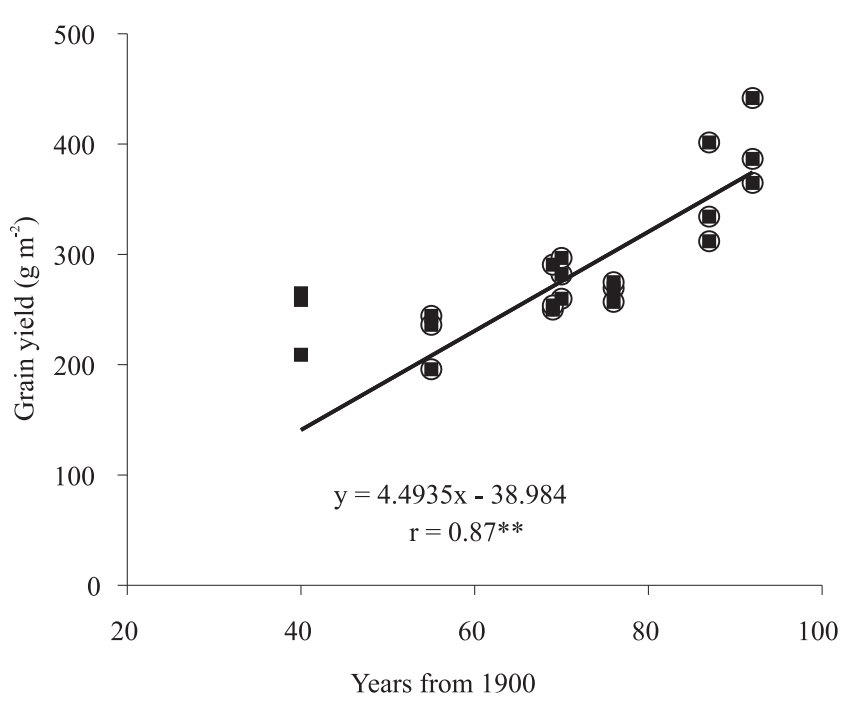

Figure 2. Genetic gain (regression coefficient of the relationship between grain yield and year of release) of wheat cultivars in Southern Brazil. (These genetic gains were estimated using only the period when the linear model was significant at $5 \%$ level).
( $1.54 \%$ per year) was higher than the observed in Mexico $(0.90 \%$ per year) and in New Zealand (1.10\% per year) (Slafer \& Andrade, 1991), and was more evident from the seventies, when cultivar IAS 54, bearing the gene Rht, was introduced. Similarly to Mexico (Waddington et al., 1986), this gene may have been the main cause of such impact on wheat yield observed in Southern Brazil after the seventies.

Plant height of the cultivars released after 1970 were significantly lower than the earlier ones. The reduction in height was maximized with the release of cultivar IAS 54, a semidwarf genotype. More recent cultivars were slightly taller than IAS 54, suggesting that the yield potential increase after 1970 was not associated with reduced plant height. Under conditions of Southern Brazil, during this period, the breeding selection was towards yield production, which brought together the plant height trait. Low height cultivars with dense canopy usually favor the development of foliar diseases reducing grain yield. So, shorter stems have been associated with increased canopy density (LAI m ${ }^{-3}$ ), and would probably decrease the uniformity of light interceptation within the canopy and crop growth rates (Flintham et al., 1997). Howerer, the plant height of moderns cultivars is close to the optimum $(80 \mathrm{~cm})$ to obtain highest harvest index and grain yield, as suggested by Richard (1992) and Flintham et al. (1997).

The changes in biological yield over time of cultivars release were adequate, and are described by the equation: $y=0.00166 x^{2}-0.178 x+11.14(r=0.78$, $\mathrm{p}<0.01$ ) (Figure 3 B). Regression analysis between harvest index and years of release of cultivars showed no significant association $\left(\mathrm{r}=0.49^{\mathrm{ns}}, \mathrm{p}<0.05\right)$ (Figure $3 \mathrm{C}$ ). Therefore, since grain yield was genetically improved during the period under study (Figure $3 \mathrm{~A}$ ), and harvest index remained practically unchanged, a major part of such advance in yield was due to changes related to total biomass production. Similar results were obtained in Mexico, with cultivars released from 1950 to 1982 (Waddington et al., 1986). In Canada, Hucl \& Baker (1987) found a significant and positive correlation coefficient between biomass production at maturity and years of cultivar release. Under different circumstances, however, the increase in yield was associated to similar increments in biomass and harvest index (Perry \& D'Antuono, 1989). Contrarily to the results obtained in this work, most of the studies on the physiological basis of genetic breeding for wheat yield indicate that biomass at physiological maturity has not changed substantially 
throughout the history of breeding programs (Slafer \& Satorre, 1994).

The variations in grain yield of the cultivars studied during this period were better associated with biomass
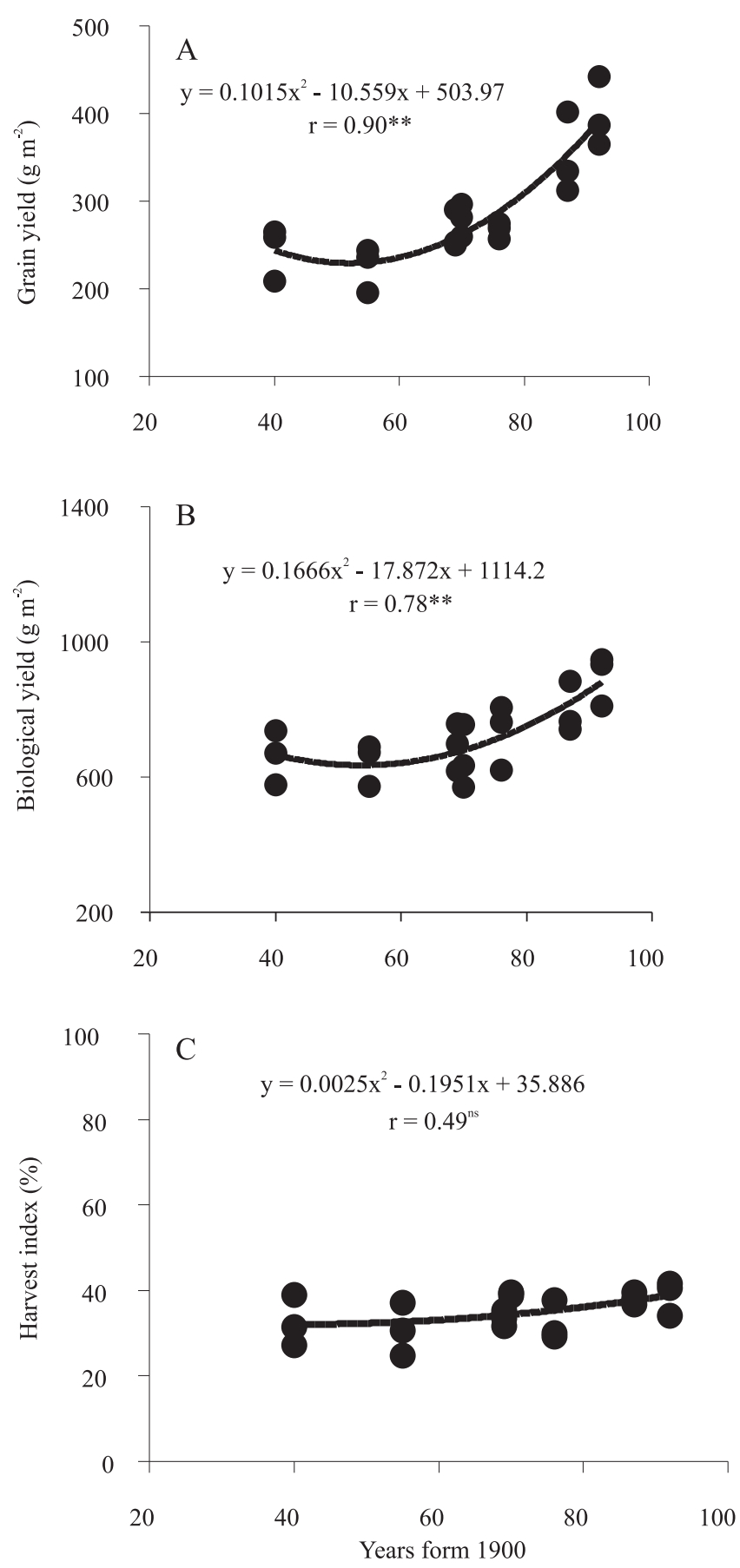

Figure 3. Association between grain yield (A), biological yield (B) and harvest index (C) of wheat cultivars and their year of release (expressed as number of years since 1900), for the 1993,1994, and 1995 experiments. production than with harvest index (Table 5). Also, stepwise multiple regression shows a greater contribution of biomass (partial $R^{2}=0.61$ ) to grain yield variation when compared with harvest index (partial $\mathrm{R}^{2}=0.36$ ).

Considering a maximum partition limit close to $62 \%$, from photoassimilates to reproductive organs (harvest index) (Austin et al., 1980), the increment in biomass could represent, under the conditions in which this study was carried out, a real possibility of advance in yield potential. Therefore, the identification and exploration of genotypes showing a greater ability to produce biomass, maintaining the present values of biomass partitioning, could be a way to increase progress in genetic breeding for yield in the future (Austin et al., 1980).

Physiological basis to increment total biomass production is normally related to the interception of the photosynthetically active radiation and the efficiency of its conversion into biomass (Gifford et al., 1984). Therefore, the best way to enhance yield under Brazilian conditions, where water deficits are often experienced throughout the wheat growing season, could be by increasing the efficiency to convert radiation into biomass, as suggested by Deckerd et al. (1985). In addition, since a direct association between an increase in biological production and taller cultivars (Brooking \& Kirby, 1981; Hanson et al., 1985) has been observed, care must be taken to prevent conditions that favor lodging, in connection with the strategies adopted to increment biomass.

The number of grains per unit of area was significantly associated with years of the cultivars release $(r=0.81$, $\mathrm{p}<0.01$ ), whereas grain yield was also closely correlated with the number of grains per unit area $(r=0.94, \mathrm{p}<0.01)$ (Figure 4). Such high correlation was observed by other authors (Waddington et al., 1986; Austin et al., 1989;

Table 5. Correlation coefficients among biological yield (BY), grain yield (GY), grain yield components (number of spikes per square meter, NS; number of grains per spike, NG; and grain dry weight, GDW), harvest index (HI) and height (H), for seven cultivars in 1993,1994, and 1995 experiments.

\begin{tabular}{llccccc}
\hline Traits & GY & HI & BY & NS & NG & GDW \\
\hline HI & $0.65^{* *}$ & - & - & - & - & - \\
BY & $0.78^{* *}$ & $0.07^{\text {ns }}$ & - & - & - & - \\
NS & $0.54^{*}$ & $0.17^{\text {ns }}$ & $0.57 * *$ & - & - & - \\
NG & $0.80^{* *}$ & $0.67^{* *}$ & $0.55^{* *}$ & $0.09^{\text {ns }}$ & - & - \\
GDW & $-0.39^{\text {ns }}$ & $-0.23^{\text {ns }}$ & $-0.33^{\text {ns }}$ & $-0.55^{* *}$ & $-0.48^{*}$ & - \\
H & $-0.52^{*}$ & $-0.73^{* *}$ & $-0.17^{\mathrm{ns}}$ & $-0.06^{\text {ns }}$ & $-0.64 *$ & $0.18^{\text {ns }}$ \\
\hline ns Nonsignificant. * and $* *$ Significant at 5 and $1 \%$ level, respectively.
\end{tabular}


Perry \& D'Antuono, 1989; Slafer \& Andrade, 1989). The results clearly indicate that breeding for grain yield was associated to a higher ability to establish grain number. That was also demonstrated by a higher association between grain yield and number of grains per spike $(r=0.80, p<0.01)$, as compared to number of spikes per square meter $(\mathrm{r}=0.54, \mathrm{p}<0.05)$ (Table 5). Number of spikes, and grains per spike per square meter were associated with high biomass $(\mathrm{r}=0.57$ and $\mathrm{r}=0.55$, $\mathrm{p}<0.01$, respectively).

No significant association between grain weight and years of release of cultivars $\left(r=0.27^{n s} ; p<0.05\right)$ or yield was observed over the period studied $\left(r=-0.39^{\text {ns }}\right)$ (Table 5). The data show a negative linear correlation between plant height and harvest index $(r=-0.73$, $\mathrm{p}<0.01)$. Also, a negative correlation was observed between grain mass and number of grains per square meter (Figure 5). Such association was observed in studies with modern and old cultivars (Waddington et al., 1986; Perry \& D’Antuono, 1989; Slafer \& Andrade, 1989). The negative association between number and grain weight, per unit area, may be primarily related to a limited amount of available assimilates (current photosynthesis and reserve generated at pre-anthesis) to meet the requirement for complete growth of all grains (Fischer \& Aguilar, 1976). In addition, a lower grain weight may be a result of an additional production of more grains, due to a higher establishment of reproductive sink. Under such circumstance, grains located at the distal point in the central spikelets or located in the spikelets at spike extremes have a lower potential to accumulate dry matter, independently of the

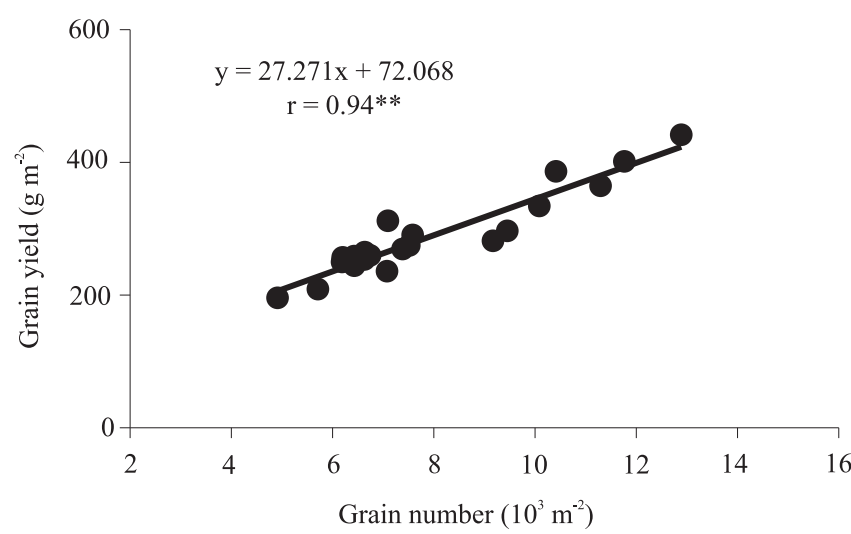

Figure 4. Association between grain yield and number of grains of wheat cultivars released in Southern Brazil between 1940 and 1992. availability of assimilates for their growth. As a consequence, a lower final average mass is observed for all grains.

The correlation between individual dry matter of grains and number of grains per square meter indicates that the reduction in dry matter of grains does not result from a compensation by the increase in the number of grains per square meter, observed in modern cultivars (Slafer \& Andrade, 1993). When this analysis procedure was followed, similar results were observed for the cultivars released between 1940 and 1992 in Southern Brazil (Figure 5). Such results indicated that the demand established for grain growth was not limited by sink capacity in either old or modern cultivars. Thus, it is possible to consider the number of grains per area unit as an indicator of yield potential. This strong association between number of grains per unit area and yield would indicate that the supply of assimilates for grain growth (source capacity), along with the reserves accumulated in the vegetative organs, at pre-anthesis stage, were enough to meet the demand of developing grains (sink capacity). The high number of grains per square meter and a sufficient production of assimilates to produce additional grains could be a result of a longer spike development period at pre-anthesis (Calderini \& Reynolds, 2000), higher crop growth rate during that period, greater partitioning to spikes or more grains per weight of spikes (Abbate et al., 1998). However, the

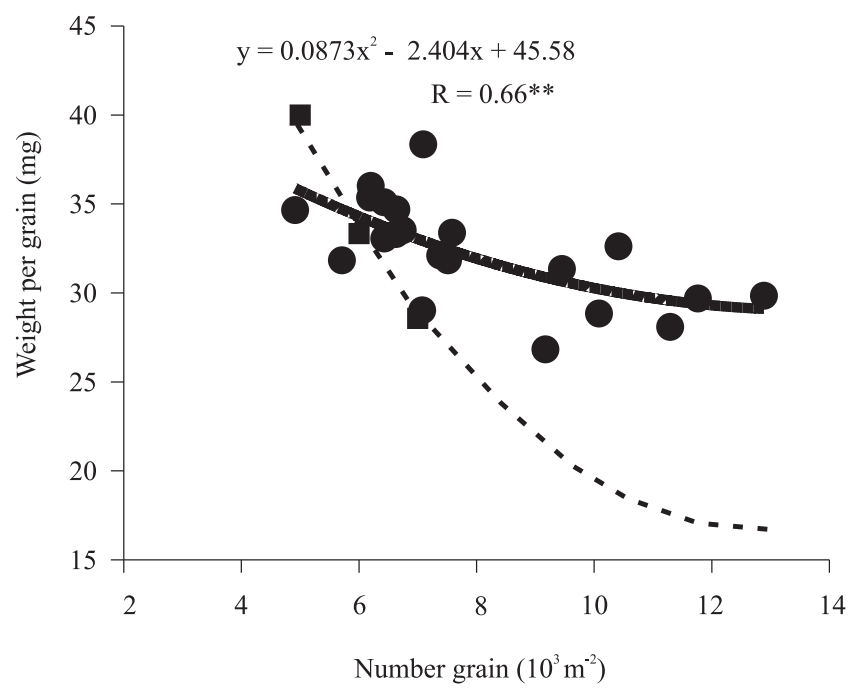

Figure 5. Association between individual grain weight and number of grains per square meter, of wheat cultivars released between 1940 and 1992. (The dotted line represents a constant grain yield of $200 \mathrm{~g} \mathrm{~m}^{-2}$ ). 
ability of changing the morphogenetic pattern within the spike, thus favoring the development of a higher number of grains per spike, that have been attributed to the gene Rht (Waddington et al., 1986), could also have contributed.

Therefore, the strategies to enhance yield should be directed towards increasing the number of grains, since, differently from that of the harvest index (Austin et al., 1980), there is no ceiling limit for it.

\section{Conclusions}

1. The average genetic gain in grain yield of wheat in Southern Brazil (44.9 $\mathrm{kg} \mathrm{ha}^{-1}$ per year), over the last 52 years, was mainly due to changes in biological yield.

2. The high yield potential of modern Brazilian cultivars resulted from an increase in the sink size (grain number per unit of area).

3. The wheat yield potential in Southern Brazil can be further improved through breeding for increasing biomass and harvest index.

\section{Acknowledgements}

To Drs. F.H. Andrade (Unidad Integrada Balcarce, Argentina), E. Minella and E.S. Roman (Embrapa Trigo), for critical reading and comments on the paper; to J.L. Rheinheimer, J. de Quadros and D. Pelissaro, for technical assistance with the field experiments; to Fapergs (Rio Grande do Sul Research Support Foundation), for partial support.

\section{References}

ABBATE, P.E.; ANDRADE, F.H.; LÁZARO, L.; BARIFFI, J.H.; BERARDOCCO, H.G.; INZA, V.H.; MARTURANO, F. Grain yield increase in recent Argentine wheat cultivars. Crop Science, v.38, p.1203-1209, 1998.

AUSTIN, R.B.; BINGHAM, J.; BLACKWELL, R.D.; EVANS, L.T.; FORD, M.A.; MORGAN, C.L.; TAYLOR, M. Genetic improvements in winter wheat yields since 1900 and associated physiological changes. Journal of Agricultural Science, v.94, p.675-689, 1980.

AUSTIN, R.B.; FORD, M.A.; MORGAN, C.L. Genetic improvement in the yield of winter wheat: a further evaluation. Journal of Agricultural Science, v.112, p.295-301, 1989.

BROOKING, I.R.; KIRBY, E.J.M. Interrelationships between stem and ear development in winter wheat: the effects of Norin 10 dwarfing gene, Gai/Rht2. Journal of Agricultural Science, v.97, p.373-381, 1981.
CALDERINI, D.F.; REYNOLDS, M.P. Changes in grain weight as a consequence of de-graining treatments at pre- and post-anthesis in synthetic hexaploid lines of wheat (Triticum durum $\mathrm{x}$ T. tauschii). Australian Journal of Plant Physiology, v.27, p.183-191, 2000.

DECKERD, E.L.; BUSCH, R.H.; KOFOID, K.D. Physiological aspects of spring wheat improvement. In: HASPER, J.; SCRADER, L.; HOWEL, R. (Ed.). Exploitation of physiological and genetics of variability to enhance crop productivity. Madison: American Society of Plant Physiologists, 1985. p.45-54.

FISCHER, R.A. Number of kernels in wheat crops and influence of solar radiation and temperature. Journal of Agricultural Science, v.105, p.447-461, 1985.

FISCHER, R.A.; AGUILAR, I. Yield potential in a dwarf spring wheat and the effect of carbon dioxide fertilization. Agronomy Journal, v.68, p.749-752, 1976.

FLINTHAM, J.E.; BORNER, A.; WORLAND, A.J.; GALE, M.D. Optimizing wheat grain yield: effects of $R h t$ (gibberellin-insensitive) dwarfing genes. Journal of Agricultural Science, v.128, p.1-25, 1997.

GAY, S.; EGLI, D.B.; REICOSKY, D.A. Physiological aspects of yield improvement in soybeans. Agronomy Journal, v.72, p.387391,1980

GIFFORD, R.M.; THORNE, J.H.; ITZ, W.D.; GIAQUINTA, R.T. Crop productivity and photoassimilate partitioning. Science, v.225, p.801-808, 1984.

HANSON, P.R.; RIGGS, T.J.; KLOSE, S.J.; AUSTIN, R.B. High biomass genotype in spring barley. Journal of Agricultural Science, v.105, p.73-78, 1985.

HUCL, P.; BAKER, R.J. A study of ancestral and modern Canadian spring wheat. Canadian Journal of Plant Science, v.67, p.87-97, 1987.

LAWES, D.A. Yield improvement in spring oats. Journal of Agricultural Science, v.89, p.751-757, 1977.

McEWAN, J.M.; CROSS, R.J. Evolutionary changes in New Zealand wheat cultivars. In: INTERNATIONAL WHEAT GENETIC SYMPOSIUM, 5., New Delhi, 1978. Proceedings. New Delhi: Indian Society of Genetics and Plant Breeding, 1979. p.198-203.

MOREIRA, J.C.S.; SOUZA, C.N.A.; MEDEIROS, M.C. Avaliação do progresso na criação de cultivares de trigo. In: REUNIÃO NACIONAL DE PESQUISA DE TRIGO, 12., 1982, Cascavel. Resumo e comunicado técnico. Cascavel: Ocepar, 1982. p.159161.

NEDEL, J.L. Progresso genético no rendimento de grãos de cultivares de trigo lançadas para cultivo entre 1940 e 1992. Pesquisa Agropecuária Brasileira, v.29, p.1565-1570, 1994.

NERSON, H.; SIBONY, M.; PINTHUS, J.M. A scale for the assessment of the developmental stage of the wheat spike. Annals of Botany, v.45, p.203-204, 1980.

PERRY, M.W.; D’ANTUONO, M.F. Yield improvement and associated characteristics of some Australian spring wheat cultivars introduced between 1960 and 1982. Australian Journal of Agricultural Research, v.40, p.457-472, 1989. 
RICHARD, R.A. The effect of dwarfing genes in spring wheat in dry environment. I. Agronomic characteristics. Australian Journal of Agricultural Research, v.43, p.517-523, 1992.

RIGGS, T.J.; HANSON, P.R.; START, N.D.; MILLES, D.M.; MORGAN, C.L.; FORD, M.A. Comparison of spring barley varieties grown in England and Wales between 1880 and 1980. Journal of Agricultural Science, v.97, p.599-610, 1981.

SAS INSTITUTE (Cary, Estados Unidos). SAS/STAT: user's guide. Version 6. Cary, 1990. 1848p.

SLAFER, G.A.; ANDRADE, F.H. Changes in physiological attributes of the dry matter economy of bread wheat (Trtiticum aestivum) through genetic improvement of grain yield potential at different regions of the world. Euphytica, v.58, p.37-49, 1991.

SLAFER, G.A.; ANDRADE, F.H. Genetic improvement in bread wheat (T. aestivum) yield in Argentina. Field Crops Research, v.21, p.289-296, 1989.

SLAFER, G.A.; ANDRADE, F.H. Physiological attributes related to the generation of grain yield in bread wheat cultivars released at different eras. Field Crops Research, v.31, p.351367, 1993.

SLAFER, G.A.; SATORRE, E.H. Increase in grain yield in bread wheat from breeding and associated physiological changes. In: SLAFER, G.A. (Ed.). Genetic improvement of field crops. New York: M. Decker, 1994. p.1-68.

TOLLENAAR, M. Physiological basis of genetic improvement of maize hybrids in Ontario from 1959 to 1988 . Crop Science, v.31, p.119-124, 1991.

WADDINGTON, S.R.; OSMANZAI, M.; YOSHIDA, M.; RANSON, J.K. The yield of durum wheats released in Mexico between 1960 and 1984. Journal of Agricultural Science, v.108, p.469-477, 1987.

WADDINGTON, S.R.; RANSON, J.K.; OSMANZAI, M.; SAUDERS, D.A. Improvement in the yield potential of bread wheat adapted to Northwest Mexico. Crop Science, v.26, p.698-703, 1986.

WYCH, R.D.; RASMUSSON, D.C. Genetic improvement in malting barley cultivars since 1920. Crop Science, v.23, p.1037-1040, 1983.

Received on December 20, 2006 and accepted on May 7, 2007 